DOI https://doi.org/10.30525/978-9934-588-37-2.1.3

\title{
SELF-HELP IN PANDEMIC AS A PROCESS OF PERSONAL GROWTH
}

\section{Baranova S. V.}

\section{INTRODUCTION}

Self-help and self-care are the basic practices in self-realization and selfdevelopment process of mature personality. As a result of conscious caring for oneself, a person is increasingly freed from the external determination of behavior associated with the vital needs, and it has an internal need for its own realization. Self-help and self-care features are related to the level of personal maturity. However, person maturity perception does not appear unexpectedly and immediately, this perception is reflexively resumed and restored every moment in all conditions, especially in crisis. Right now, in the context of the pandemic, wich our society is experiencing, the question of self-determination for the person (definitely awaring of human self) what will happen next, how can I help myself right now?, what can I do for myself in self-isolation conditions? what in my place can I do for the future? - which need to be answered first and foremost for yourself. The delay in determining the answer to these questions in today's pace of events and in society as a whole can cost price (examples shows present), incompatible with life.

It has always been difficult for people to come to terms with modern times and social transformations, but the gap between the new and the old has never been as deep as it is today because of the spread of the COVID-19 virus. The real threat to the life of all humanity. This gap, the mismatch between subjective and objective dimensions and times, attitude towards them, towards changes in, which are taking place in reality, are a catastrophic threat to humanity as a whole. Never has the future seemed so uncertain because of the catastrophic threat to all of humanity as a whole. Despite the highest level of education and technological development in the history of mankind, there are currently no drugs to sustain death or death threat. The existential fear of the coronavirus reigns in society as a crowned lord. It sets new norms and rules of his own accord that lead to the change of existing social ties, disintegration of traditional values, the inability to offer a new socially significant ideal of a person with a humane personality and to recognize universal values. 
So, today, social psychology is faced with the need for careful theoretical and applied consideration of the problem of self-help and self-care as a conscious process of self-development of the individual in accordance with the real conditions of self-isolation as a specific person, and as society as a whole. In our opinion, it is relevant to study the psychological foundations of the transformation of ideas of negative experience in the context of the pandemic of 2020 as the basis of personal growth.

The purpose of the article - theoretical analysis of the peculiarities of personal concern for oneself as a process of personal growth in the current conditions of a pandemic as a social crisis.

\section{Pandemic as a socio-cultural crisis}

Forced self-isolation has become a stiff barrier to the ordinary lifestyles of all citizens in almost every civilized countries in the world.

Everybody, even biologists and virologists argue about the danger of the virus, but public opinion makes its verdict: save yourself, who can!

In such a situation, deep defense mechanisms are triggered: stop (stopping active and habitual lifestyle), run (runnig away from the "source" of contagion to hide in a secluded corner of your own apartment) and hit (looking for the guilty, attacking the enemy - sending sneezed home or in the hospital for quarantine, we require colleagues and even strangers to wear masks, to wash their hands).

The basic idea of a crisis can be symbolically represented as a counterpoint, which combines two transformational tendencies: outside and inside out in relatively of human. From the outside (society) there is a lack of a single intellectual space with a stable hierarchy of generally accepted values. On the other side, internally (from the depths of subjectivity), there are also transformational derivatives related to certain factors.

Thus, transformation processes affect the values of the individual at all levels of it's functioning as a subject of activity: at the level of values of relationships, values of experiences, values of creativity. Long term of such exposure can lead to deprivation or destruction. Therefore, the problem of personal development in transformational conditions is acute.

The determinants of personality change can be both internal (motivational, genetic) and external (socio-cultural and situational) contradictions that determine the dynamics of personality plasticity and stability. In general, the process characteristic involves movement, change, stability, repeatability, reproducibility. Maturity is not a process, though it has indicators (criteria) and it is a unit for the study of its manifestations, which concerns the dilemma: isolation against community, which shows the criteria for the possibility of creative interaction with reality, which adequacy is secured by supersituative management and acceptance of 
responsibility for their actions, and their consequences. However, it has a basis for creativity, spontaneity and unpredictability. As noted, the characterization of maturity as a process is due to the tracking in time and dynamics of its indicators. Changing these indicators can show the peculiarities of maturity as a process. Only in the current process can the "past-present-future" triad be applied.

Therefore, the self-creative work of the body requires the use of energy, which is released during the destruction of other systems. "To put it bluntly, to live means to destroy"1.

In such circumstances, the creation of stability and integrity of personality, which is largely provided by tradition, religion, stable monoculture, now, in a multicultural, transitive situation, becomes the fate of the individual, requiring her to carry out a continuous work that has a beingtemporal, cultural-historical plans (for survival and development, for reproduction of culture and its production) (M.S. Magomed-Eminov, 2009). According to the dialectical laws of philosophy, where is destruction, there is also creation, and vice versa. However, unfortunately, in reality, humankind does not always have the resource and ability to search creatively in the depths of the devastating and wait for one to turn into another.

According to synergistic principles, the operation of an open system is an unproven anti-entropy process, continual work, opposed to counterbalanced ambient pressure. Therefore, we cannot explain the destructive activity using separate elements of a separate system. According I.V. Lysak, "at a certain level of complexity of the system, it has properties that do not flow from the properties of its elements", "And therefore it is possible to find out the essence of a destructive manifestation only by analyzing the personality as a whole system"2. According to "But, - A.P. Nazarethyan writes, - the basic physical law of irreversibility, the second beginning of thermodynamics say, anti-entropy processes in the system are possible only due to the growth of entropy in another system".

The most common means of ensuring a system's dynamic equilibrium, saving through change, is fluctuation. Based on I.B. Blauberg terminology, it can be argued that all systems have subsystems that are constantly

Лысак И.В. Философско-антропологический анализ деструктивной деятельности современного человека. Ростов-на-Дону - Таганрог: Изд-во СКНЦ ВШ, Изд-во ТРТУ, 2004. 160 с. URL: https://destructivnost.ru/index.php/ sinergeticheskij-podkhod-k-destruktivnosti

Лысак И.В. Философско-антропологический анализ деструктивной деятельности современного человека. Ростов-на-Дону - Таганрог: Изд-во СКНЦ ВШ, Изд-во ТРТУ, 2004. 160 c. URL: https://destructivnost.ru/index.php/ sinergeticheskij-podkhod-k-destruktivnosti 
fluctuating ${ }^{3}$. Sometimes a single fluctuation or combination of fluctuations can become (as a result of positive feedback) so strong that an existing organization does not sustain and collapse. At this turning point, indicated as a bifurcation point, it is fundamentally impossible to predict in which direction the further development will take place: will the state of the system be even more chaotic, or will it move to a new, higher level of organization, which systematic methodologists called dissipative structure, and divided two opposite trends:

- striving for stability, self-preservation, stability, homeostasis;

- striving for diversity, variability, stochasticity and uncertainty.

In our view, the situation with the COVID-19 implementation across the globe is such a point of bifurcation when there is no return path. On the one hand, resource flows and random fluctuations provoke an increase in the level of the control system, which leads to increased chaos and, eventually, can lead to its destruction. On the other, the system seeks to maintain stability by restructuring and forming a new order, thereby reducing entropy. Which one will be reviewed, depending on many random factors, and will determine external and internal conditions as well as the quality of the resources available.

The passing of the point of bifurcation creates the possibility of a picture of possibilities as a set of ways of perspective development. The choice depends on the fluctuation - randomness.

\section{The situation of uncertainty as an indicator of socio-cultural crisis}

Increase of the number of social uncertainty situations is estimated as a leading feature of the postmodern era (see, for example, Shotter, 1987), and postmodern reality is multiple. "Disobedience in Being" M. Heidegger's, "Spontaneity of Everyday Life" B. Waldenfels's, "Being-Between" S. Kierkegaard's, reflects, in essence, the same pathos of the human problem in the modern world - the pathos of its (human) incompleteness, the actual lack of orientation to fixed role models, absolutization of freedom of choice. Reality of the first quarter of the twenty-first century gives huge amount of reasons for such existential elections. A pandemic due to the coronavirus of the winter-spring 2020 period has taken its place of honor in this list.

The concept of "uncertainty" is nowadays widely used in various fields of knowledge and is not exclusively "belonging" not only to social psychology but to all humanitarian knowledge as a whole. Both the physical and social worlds are filled with many "uncertainties", and the natural sciences and humanities are increasingly promoting the task of

${ }^{3}$ Блауберг И.Б., Юдин Э.Г. Становление и сущность системного подхода. М.: Наука, 1997. 226 с. 
distinguishing features of uncertain situations and, accordingly, of their typologies ${ }^{4}$. Most often, uncertainty studies consider the information criterion that is identified by "lack, inconsistency, or inaccuracy of information". Proponents of this trend rely on understanding the informational causes of uncertainty in the context of classical decision theory, which is based on the principle of rationality, that is, the idea of the subject of the decision as a system that assesses the likelihood of results and the degree of risk of each. Thus, a person was understood as implementing only a number of regulatory strategies, and the idea of uncertainty narrowed down to quantitative measurement of results and their probabilities ${ }^{5}$.

This, of course, was a certain rational grain - due to the apparent diversity of internal sources of uncertainty in their consideration within the experimental approach, it seemed quite complicated. Today, there are a number of experimental data (O. Polunin, 2011) that prove that not only and not so much objective parameters of an information field gives characteristics of a situation of uncertainty, but subjectively attributed features of information flow force a person to evaluate the decision-making situation as more or less defined ${ }^{6}$.

The characteristic of the information parameter of uncertainty is implicitly contained in those contemporary social and psychological studies that turn to the analysis of situational changes. As a rule, manipulation of situational parameters in the laboratory experiment is possible on the line "regulation / non-regulation"7.

For most socio-psychological approaches, in addition to the information trait, researchers isolate the incompatibility of two or more cognitions (Bauman, 1996; Kagan, 1972). It should be noted that such incompatibility is considered, including, on the "axis of time" - as the presence of simultaneous discrepancy or as incompatibility of current and past knowledge. Being traditional enough for social psychology, this approach to the problem is practiced in virtually all cognitive concepts. It has its maximum expression in L. Festinger's theory of cognitive dissonance (Festinger, 2000). As we know, seeking to reduce the onset of cognitive

${ }^{4}$ Гусєв А.І. Толерантність до невизначеності як чинник розвитку ідентичності : автореф. дис. ... канд. психол. наук : 19.00 .05 ; Південноукраїнський національний педагогічний університет імені К.Д. Ушинського. Одеса, 2009. 20 с.

5 Корнилова Т.В. Психология риска и принятия решений. М.: Аспект Пресс, 2003. 286 c.

6 Полунін О.В. Переживання людиною плину часу: експериментальне дослідження : монографія. К.: Гнозіс, 2011. 360 с.

7 Белинская Е. П. Идентичность личности в условиях социальных изменений: дис. ... докт. психол. наук : 19.00.05 ; Московский государственный университет им. М.В.Ломоносова. Москва, 2006. 419 с. 
dissonance, human can try to change or eliminate one of the inconsistent elements - at any rate - at the level of their perception or assessment ${ }^{8}$.

In studies of subjective representation of uncertainty as a situation of unsure and risk, so-called models of expected value and utility in a situation of uncertainty are studied. In context of subjectivism, they are also regarded in correlates of relations as manifestations of individual strategies of mastering oneself (Belinska, 2006).

In general psychology and psychology of personality, ideas of the situation of uncertainty, as a special methodological position, were formulated in the concept of probabilistic functionalism by E. FrenkelBrunswick, whereby the concept of uncertainty acquired the status of independent psychological category, above all, in general psychology. The basic meaning of the concept of probabilistic functionalism can be formulated in the following two provisions:

1) the environment a living organism lives in and operates, indefinitely and unpredictably by nature, and in order to survive, the organism must be able to adapt to this uncertainty;

2) there is no strictly unambiguous relationship between external influence and its peripheral, sensory effects in the body, on the one hand, and the central conditions (needs) of the organism and its peripheral behavioral effects, on the other' .

A number of engineering and psychological works present another point of view, where the uncertainty of a situation implies, above all, the impossibility (as a rule, objective) of control by the subject of action. In most cases, the main subject of the study is the individual stability of the subject, which unfolds under similar conditions (for example, the operator) (Leonova, 2004). In this point of view, actualy, uncertainty arises when the perceptual setting of a person "come across" on a certain information barrier, expressed either in insufficient knowledge of the situation or in the lack of ability to act in it $^{10}$.

Obviously, that the isolation of such a characteristic of a situation of uncertainty as the impossibility of subjective control over it is rather conditional. This conditionality is determined by the degree in this control is understood as subjectively possible. In this sense, the defined parameter of

\footnotetext{
${ }^{8}$ Фестингер Л. Теория когнитивного диссонанса. СПб.: Речь, 2000. 320 с.

${ }^{9}$ Белинская Е. П. Идентичность личности в условиях социальных изменений: дис. ... докт. психол. наук : 19.00 .05 ; Московский государственный университет им. М.В. Ломоносова. Москва, 2006. 419 с.

10 Леонова А.Б. Комплексная стратегия анализа стресса: от диагностики к профилактике и коррекции // Психологический журнал. 2004. Т. 25. №2. С. 75-85. URL: http://naukarus.com/ kompleksnaya-strategiya-analiza-professionalnogo-stressa-ot-diagnostiki-k-profilaktike-ikorrektsii
} 
uncertainty is closely connected with another concept - tolerance / intolerance to uncertainty. There are two points of view in that sense. According to the first one, tolerance for uncertainty is a characteristic of the cognitive style of personality (this position is based on T. Adorno's views), and according to the second one, the level of such tolerance is conditioned by social culture (concept of G. Hofstede, 1980).

From this point of view, is interesting the interpretation of O.G. Lukovitska ${ }^{11}$. Scientists understand the uncertainty like a situation wich the perceiver cannot categorize because of insufficient information, that is, as complex, new, and contradictory (Lukovitska, 1998). Here is added the time parameter, when the indefinite situation can last, according to the author, "indefinite" time, its duration is unknown to the subject of the situation. We believe that for socio-psychological interpretation of uncertainty, the last sign, on the one hand, is very important, because one of the reasons for the difficulty of adapting people to social change is the inability to predict the duration of change and, as a consequence, the temporal parameters of one's own activity (Matsumoto, 2003).

However, the use of this parameter, on the other hand, obviously poses some problems: because the "unknown for how long" the long-term situation is no longer a situation in the strict sense of the word, and then arises the question of strategies for mastering or adequacy of social behavior in uncertainty $^{12}$.

Thus, the uncertainties identified are the most represented: novelty, complexity, contradiction, inability to control, multiple choices and decisions, and a high degree of risk associated with. However, the information feature of a situation of uncertainty, most likely, does not have a decisive influence on its subjective experience, it forcing some researchers to think that the perception of uncertainty is based not so much on the objective parameters of the situation as its subjective assessment.

It should be noted that not always the social situation of uncertainty for a person is assessed as a good: such a social restructuring of the processes of maturity, which requires multiple "switching", such a daily fragmentation of social being makes the processes of reflection redundant, requiring the individual only to identify oneself, only the "façade" (in I. Hoffmann's terminology) of personality (Baumeister, 1995). It is "maturation", as this or that degree of maturity, that already presupposes conformity, adequacy to certain external requirements and the conditions which this maturity is

11 Луковицкая Е.Г. Социально-психологическое значение толерантности к неопределенности : автореф. дис. ... канд. психол. наук : 19.00.05 ; СанктПетербургский государственный университет. Санкт-Петербург, 1998. 19 с.

${ }^{12}$ Мацумото Д. Психология и культура. Санкт-Петербург: Питер, 2003. 720 с. 
determined; out of these external conditions, maturity loses its internal content ${ }^{13}$.

The idea of the social nature of destructive factors is reflected in classical philosophy (E. Durkheim, E. Fromm, etc.) and modern sociology. Destructiveness is seen as a form of activity of the subject, aimed to destruction of external structures and the construction of their own, different from other structures of the image, when individualism becomes one of the priority forms of activity. In this situation, human destructiveness is a way of self-determination when other paths are unattainable; in simplified form, it is reaction to the inability to exercise identity. According to Z.V. Sprinska, destructiveness and aggression become one of the means of achieving life goals.

\section{Psychological reactions to the pandemic situation}

On the premises of the FB there is information that anthropologist Margaret Mead once asked students what they consider to be the first sign of civilization. Students expected Mead to talk about fishing hooks, clay pots or stones.

But no. Mead said that the first sign of civilization in ancient culture is the femur, which was broken and then fused. Mead explained that if a living creature in the animal kingdom breaks a leg, it dies. With a broken leg, it cannot run from danger, get to the river to get drunk or hunt for food. It becomes a prey for predators because the bone grows for a long time.

The femur, which was broken and then fused, is proof that someone has spent time to stay with the one who received the injury, bandaged the wounds, moved the person to a safe place and guarded him until he recovered. Helping another person during a difficult period is the act from which civilization begins, said Mead.

In the context of a real sociocultural crisis which linked to the pandemic and engulfed our country, in the process of providing psychological assistance to people who seeking help during forced self-isolation, we have recorded major complaints and manifestations of emotional state in response to the events of restriction. So, here is a list of "broken hip bones" that should be able to coalesce.

Applying a system-based analysis, we distinguish the following:

- Feeling angry and anger because of severe constraints (when all this is over, my plans are destroyed);

- fear of getting sick with almost any disease (there is no cure, if I have a toothache, I will contract the virus);

${ }^{13}$ Парсонс Т. Система современных обществ. М.: Аспект Пресс, 1998. 270 с. 
- irritation: in power (why they don't do anything), restrictions (why they take so long), medicine (why they don't treat), children (why they don't sleep), the Internet (the internet is hanging) ect;

- feeling completely exhausted and powerless (I have absolutely no strength, I cannot stand it);

- fear of the future (as it will never end), of the unknown (what the world will be like after), the fear of hunger (money will run out, the payment of credit);

- existential fear (we will all die);

- the tension that accompanies the effort required for both psychological and domestic adaptation in forced self-isolation;

- feelings of loss (freedom, mobility) or deprivation of the habit of socializing (birthdays without friends, only in a Skype, Easter holidays without elderly relatives);

- mental pain (from their own inability and powerlessness for their relatives, for the future of children, for their elderly parents);

- tension that accompanies suspicion associated with any interaction with others, such as in a pharmacy or store (he has coronavirus, he spreads an infection);

- exacerbation of somatic diseases;

- failure in values, feelings (any money for a mask, or for medicine);

- feelings of anxiety based on different emotions (surprise, disgust, indignation) result from realization of reality;

- feeling of inferiority due to inability to master a new situation.

Thus, in many people experiencing a pandemic-related situation of selfisolation, these phases of psychogenic reactions are indeed observed, which can be the result of a psychological trauma and are determined not by its nature but by its intensity (in particular, they depend very little on whether the traumatic situation was local or mass).However, it should be remembered that the causes of psychological trauma and crises almost never lie completely out the human psyche. Even a seems, purely external, objective event leads to a crisis, not by itself, but as a result of its certain perception by the subject.

\section{Crisis as a condition of personality psychological growth}

The inability to contradict the fear of change and the oppression of suffering is the most effective indicator of a person's desire to overcome a crisis. According to J. Bügenthal, suffering contains the powerful force of positive personal change. It is also the most important impetus to force a person to make the decision to seek professional help from a psychologist. However, he argues that suffering is not enough, however strong it may be, is clearly not enough to change one's life for the better ${ }^{14}$.

14 Бьюдженталь Дж. Наука быть живым. Диалоги между терапевтом и пациентами в гуманистической терапии. Москва : Независимая фирма «Класс», 1998. URL: http://www.koob.ru/byudjental_j/nauka_bit_jivim 
Despite the differences in the understanding of processes and mechanisms of personality change in different approaches, a universal postulate is the action of different and conflicting forces, which describe the contradictions of the properties of plasticity and stability of the individual in the interaction in specific conditions.

In a pandemic situation, opportunity to take the necessary experience, enriching your life experience, are driven by powerful challenges that change the value system that brings together all levels of maturity integration as a system. Thus, changes in values occur at all levels of functioning of the individual as the subject of activity: at the level of values of relationships, values of to worries, and at the level of values of realization and creativity. We consider the features of self-help for ourselves through the holistic and generalized socio-psychological concept of personal maturity and responsibility developed in the context of social transformations, which has become new today, especially in a pandemic ${ }^{15}$.

Personal growth is directed to a controlled process of self-realization as a conscious process of reflexive self-change, as a restoration of infantile developmental needs that have not previously been fully or sufficiently, leading to deficits in personality structure and possible destruction. There is reason to speak only of the most general "basic law of personal growth", which, based on the famous formula of K. Rogers "if-then" (Rogers S., 1959), can be formulated like: if there are appropriate conditions, then in the person actualized process self-development, the natural consequence of which will be changes aimed at her personal maturity. In other words, it is these changes - their content, orientation, dynamics - that shows the process of personal growth and the achievement of a person's personal maturity. However, mindfulness and commitment make it possible to go beyond one's own limitations. The student of V. Frankl A. Pattakos in the book "Hostages of own thoughts ...", published in russian in 2009, cites an ancient source of unknown origin, found by him in a library in Hawaii. "There is a gap between stimulus and response. In this interval is our freedom, our ability to respond to circumstances. In our answer is our destiny, our happiness" ${ }^{\prime 16}$. In our opinion, this gap is similar to a pause between inhalation and exhalation, unnoticeable at first glance, but for people who know their inner and outer world through the features of controlling the process of breathing (such as holotropic breathing), this pause is an important and significant

15 Баранова С. В. Концепція особистісної зрілості в умовах суспільних трансформацій. Проблеми політичної психологї ; Нац. акад. пед. наук України, Інститут соц. та політ. психології ; за заг. ред. М.М. Слюсаревського. Київ : Міленіум, 2017. Вип 5 (19). С. 133-144.

16 Паттакос А. Пленники собственных мыслей: Смысл жизни и работы по Виктору Франклу. М.: Альпин Бизнес Букс, 2009. 205 с. 
stage. Like the transition between white and black fish in a symbolic image of yin-yang, which are woven with tails. It was this sign 7,000 years ago that the ancient Chinese called "the sign of change". It is this pause that breaks the script's unconsciousness, given by the "stimulus-response" scheme. With awareness, we have the opportunity to live by another formula: "incentive freedom of choice - reaction". This, in our view, is true freedom, which is based on an evolutionary approach and involves the involvement of selfawareness when a person acts as an outside observer of what is happening inside and around him. Thus, self-help and conscious care for oneself in the conditions of self-isolation emerges as a creative realization and a condition of personal growth and a priority task for everyone. Crisis contradictions present new challenges and, at the same time, new opportunities for conscious self-change and personal growth.

Our research is based on the fact that responsibility and personal maturity are dynamic; The unit of increasing responsibility and measuring maturity is living a psychological situation of personal growth, which is solved through creative transformation of reality or psychological coping. Frustration of the desire to meet a basic need, such as the desire for recognition, in a certain dimension of psychological space due to the symbolic nature of the latter leads either to the substitution of this dimension by another, or to a decrease in the level of maturity (deprivation or destruction), or to an overamplification (overcontrol and hyperresponsibility). In addition, the desire to meet the basic need will dominate until the need is met. Such violations can be offset in the course of natural life or purposeful socio-psychological influence, which is accordingly to increase awareness of one's own worth and to recognize the sovereignty and value of another person and it's needs.

The psychological situation of personal growth we regarded as a reflexive self-change of the system of own subjectivity because of the possibility of trans-situational management and acquisition of responsibility as a result of satisfaction of self-inquiry as a process of updating the system of personal maturity. Responsible care for oneself, as personal growth, does not eliminate the deep mental suffering associated with confronting a crisis or trauma. Growth and development during a crisis have no analgesic effect. The phenomenon of spiritual growth is more likely to be associated with the use of this painful process as a path for internal development and overcoming, that's why it is especially important at this time to realize the importance of supporting the Other.

The mechanism of personal growth is a reflexive act of self-change, generated by the meta-need of the individual in self-change and the conscious desire to attain the desired "I" in the presence of an objectively available and subjectively tangible resource for such achievement. A series of acts of self-change as a supersituative control in the process of 
self-realization of the personality is a process of personal growth, which can grow into a whole life-long process, a way of constructing the life path of the individual and defines the peculiarities of the process of becoming personal maturity.

Ontologically, the increasing variability of the modern social world naturally enhances the vector of self-development as a virtually single structural moment: in the context of accelerating social dynamics, only the person becomes "the ultimate measure of things", and it's subjective reality (values, images, identifications, etc.) not only show's these dynamics, but also become an active element in the process of constructing social reality.

The logic of personal growth consists in the internal living of the situation of personal growth, which was determined by a deficient stage of development or in creative interaction with the reality of the newest challenges. Reflectivity of own subjectivity and taking responsibility in the process of personal growth are the result of self-change, taking the consequences of responsible decisions as a result of satisfying self-inquiry as a process of updating the system of personal maturity. We have already considered the concept of self-inquiry, which we fill with content as a reflexive form of meta-need of the individual in the change, but because of the urgency of the situation, we consider it appropriate to consider this aspect again ${ }^{17}$. Self-change is defined as the internal conscious state of an individual, driven by his or her perceived need for self-development, selfrealization and self-actualization, which is a deep source of all forms of his activity and acceptance of responsibility for himself.We have found that psychologically, the process of taking responsibility by a subject involves the following steps:

1. Reflectivity of contradictions as their awareness, monitoring and rethinking (contradictions or conflicts of interests or identities, images of past and future, etc.) in the process of choosing alternatives, formation of self-request for responsibility in the process of self-development;

2. Search for an expert position (as criteria for decision-making) that will perform the function of the future instance. Depending on the locus of control, in the intersubject space - an external instance; in intersubjective space - norms, values, meanings, myths in subjective space of personality;

3. Dialogue of the expert position in the form of feedback in different forms of construction (norms, frames, schemes, models, scenarios,

${ }^{17}$ Baranova S. Theoretical analysis of responsibility as an integrative quality of personality maturity in conditions of transformation. Development and modernization pedagogical and psychological sciences: the experience of Poland and the prospects of Ukraine : Collective monograph. Lublin : Izdevnieciba "Baltija Publishing", 2017 : Maria Curie-Sklodowska University. Vol. 1. P. 37-53. URL: http://repositsc.nuczu.edu.ua/ bitstream/123456789/6063/1/colmon\%20Lublin_ped_psyh_Часть\%201_новий.pdf 
stereotypes, patterns, etc.), that is, change of decision criteria as a basis for making results;

4. Making an informed decision about the alternatives considered as a reflectivity of the feedback, which individual - according to actual selfinquiry - transforms into his own life world, thus constructing a certain integrity and maturity from the subjectively selected needs of self-change into actual response;

5. Comparativeness of the decision as a new value in the system of own values, as a result of integration into the system of personal maturity of the consequences of activity, as a condition for further self-development;

6. Persistence and conscientiousness in the implementation of the decision, the willingness to take risks and the adoption of results and unintended consequences;

7. Reflectivity of one's own subjectivity and taking responsibility for self-change, taking the consequences of responsible decisions in result of satisfying self-inquiry as a process of updating the system of personal maturity ${ }^{18}$.

The analysis of the stages of taking responsibility gives the subject an opportunity to understand responsibility as an integrative property of maturity precisely in the socio-psychological context. The search for an expert position is carried out in the space of interaction (with oneself, the Other, with a small group, society) and is based on the adoption of socio-role norms and the emergence of a relationship of trust and significance (for decision making) to the actual situation in a particular historical reality in that part of the world the individual plans to interact with and evaluate it as dangerous (reliable). Thus, for the mature exercise of self-management of the self-realization process and adequate interaction with reality, the personality must manifest itself in two dimensions: "finding oneself" and "correlation with other people", which is a universal and integrative component of the function of the psyche as a healthy narcissism. This assessment must be obtained through additional identification with the object evaluation function for the internalized function. It is important to note that the nature of the mother's reflection function and identification child with her determine the degree and quality of future assessment of own "I'm - subject" of the personality in the discussed function, according to the models provided by them and symbolized in the peculiarities of the

18 Baranova S. Theoretical analysis of responsibility as an integrative quality of personality maturity in conditions of transformation. Development and modernization pedagogical and psychological sciences: the experience of Poland and the prospects of Ukraine : Collective monograph. Lublin : Izdevnieciba "Baltija Publishing", 2017 : Maria Curie-Sklodowska University. Vol. 1. P. 37-53. URL: http://repositsc.nuczu.edu.ua/ bitstream/123456789/6063/1/colmon\%20Lublin_ped_psyh_Часть\%201_новий.pdf 
architecture of the inner world of personality. When a child begins to use them on their own, it's become separated from the mother who has ceased to strictly represent the function of presenting the part of the future of one's holistic "I". However, in times of crisis, models become inadequate to achieve certain goals and meet needs, the internal (object) is lost, that leads to anxiety, devastation and pain. For avoidance of pain and anxiety, the search for models (resources) from the intersubjective space goes to the outside world. That leads to an increase of violation of boundaries of others, the form of existence of boundaries "I" has transforming, the organization of psychological space is changing. Thus, we assume when the adequacy of the function of reflection and identification is impaired in a crisis, which determines the degree and quality of future assessment by own "I", if recreate such social and psychological conditions, then the individual may experience himself and his object world as living and symbolizing experience in new social and psychological conditions. In our assumption, we rely on the fact that identification acts as a link to the object. Unlike the introject, identification does not retain a psychologically experienced connection with the object, but transforms aspects of that object into structures of the Self that already have a historical, rather than empirical, connection with the object. This connection is manifested in the symbolic order of the characteristics of the architecture of the inner world of the individual. This feature makes it possible to simulate the situation of restoring the adequacy of the reflection and identification function in the facilitative conditions of group interaction.

The result of satisfying the need for self-inquiry will be seeing and understanding oneself as the subject of transformative dialogue, bringing adequate alignment the activity of the individual to the internal motivation and external normative-role requirements while deviating the parameters of activity from some optimum in the situation of reality. The formation of personal maturity reflects the peculiarities of the process of manifestation of maximum adaptability and self-realization of the personality through their manifestation in specific conditions. In this case, we are talking about the possibility to observe the process in the dynamics of manifestation. The formation of personal maturity, mediated by the acquisition of personal responsibility, is a non-linear and uneven process.

The dynamic structure of the process of becoming personal maturity in the context of transformation of the social situation of personal growth includes:

- the conscious objective need of the individual for his/her own development / growth; the reflective position of the individual in the system of social relations; 
- the dynamics of acquiring a new social position of identity as reflection, acceptance, residence, transformation, appropriation, verbalization and symbolization by the personality of the social position in the form of an orientation image;

- new forms of cooperation and acceptance of responsibility.In a society of transformation, responsible personal maturity is the quality of the subject, which determines responsible ways of self-realization in the intersubject space and becomes a social and psychological condition for self-realization of both oneself and the Other. Only in the conditions of recognition of one's own authorship as a result of supersituative management of the process of adequate interaction with reality a person can realize responsibility in the current time and in the future. The acceptance of one's own responsibility for oneself and one's life is based on the acceptance of one's own value (self-worth).

\section{CONCLUSIONS}

Thus, the conditions that have arisen from the spread of COVID-19 in the world today can be called a crisis. The real threat to life, the uncertainty of the prospects of further being cause a great number of problems that touch on the issues of existence of each individual and humanity as a whole. The theoretical mastery of problems of this level is possible through the use of systematic analysis. Based on a systematic analysis, the pandemic can be seen as a socio-cultural crisis, which is caused by a situation of uncertainty. The worldwide spread of COVID-19 virus is the point of bifurcation of the system when there is no turning back, but there is a map of new opportunities and prospects for development.

In such circumstances, self-help and conscious self-isolation becomes a first priority for everyone. Crisis contradictions present new challenges and, at the same time, new opportunities for conscious self-change and personal growth. In this case, the result of self-change will be a reflection of one's own subjectivity and taking responsibility for one's life, as satisfying the natural meta-need of one's personality and an awareness of the desire to attain the desired "I" when possessing an objectively available and subjectively tangible resource for such achievement.

Exactly living a crisis problem-conflict situation requires a person to change his lifestyle, way of thinking, way of knowing and seeing the world, attitude to itself and others, which, as a consequence, can lead to personal growth. The situation that has arisen from the spread of the COVID-19 virus poses a real threat to the lives of all humanity. There are no answers to this level of threat in the history of humanity, and this is a matter of concern. In such circumstances, an indicator of a mature adequate attitude will be self-help and consciously caring for themselves and their loved ones. Self-isolation is the responsibility of almost all humanity to stop the spread of the coronavirus. 


\section{SUMMARY}

The article presents an analysis of the process of personal growth in the context of a pandemic 2020. Based on a systematic analysis, the pandemic is considered as a social crisis due to the situation of uncertainty. It has been found that the worldwide spread of COVID-19 virus is the point of bifurcation of the system when there is no return path, but a map of new opportunities and prospects emerges. The analysis of psychological problems and complaints that were identified and systematized in people who sought help from a psychologist during the forced isolation period is presented. Assumptions between the features of self-care and those of conscious concern for themselves and their relatives and the level of personal maturity are proved. The psychological characteristics of the stages of the process of acquiring responsibility as a conscious self-change of personality are presented. It has been found that living in a crisis, such as a pandemic, provides new opportunities for the individual to consciously relate to his or her own life and the life of others, thereby leading to personal growth.

\section{1. Лысак И.В. Философско-антропологический анализ} деструктивной деятельности современного человека. Ростов-на-Дону Таганрог : Изд-во СКНЦ ВШ, Изд-во ТРТУ, 2004. 160 с. URL: $\quad$ https://destructivnost.ru/index.php/sinergeticheskij-podkhod-kdestruktivnosti

2. Блауберг И.Б., Э.Г. Юдин. Становление и сущность системного похода. Москва : Наука, 1997. 226 с.

3. Гусєв А.І. Толерантність до невизначеності як чинник розвитку ідентичності особистості : автореф. дис. ... канд. психол. наук : 19.00.05 ; Південноукраїнський національний педагогічний університет імені К.Д. Ушинського. Одеса, 2009. 20 с.

4. Корнилова Т.В. Психология риска и принятия решений. Москва : Аспект Пресс, 2003. 286 с.

5. Полунін О.В. Переживання людиною плину часу: експериментальне дослідження : монографія. Київ : Гнозіс, 2011. 360 с.

6. Белинская Е.П. Идентичность личности в условиях социальных изменений : дис. ... докт. психол. наук : 19.00.05 ; Московский государственный университет им. М.В. Ломоносова. Москва, 2006. 419 с.

7. Фестингер Л. Теория когнитивного диссонанса. Санкт-Петербург : Речь, 2000. 320 c.

8. Леонова А.Б. Комплексная стратегия анализа стресса: от диагностики к профилактике и коррекции. Психологический журнал. 2004. T. 25. № 2. C. 75-85. URL: http://naukarus.com/kompleksnaya- 
strategiya-analiza-professionalnogo-stressa-ot-diagnostiki-k-profilaktike-ikorrektsii

9. Луковицкая Е.Г. Социально-психологическое значение толерантности к неопределенности : автореф. дис. ... канд. психол. наук : 19.00 .05 ; Санкт-Петербургский государственный университет. СанктПетербург, 1998. 19 с.

10. Мацумото Д. Психология и культура. Санкт-Петербург : Питер, 2003. $720 \mathrm{c}$.

11. Парсонс Т. Система современных обществ. Москва : Аспект Пресс, 1998. $270 \mathrm{c.}$

12. Бьюдженталь Дж. Наука быть живым. Диалоги между терапевтом и пациентами в гуманистической терапии. Москва : Независимая фирма «Класс», 1998. URL: http://www.koob.ru/ byudjental_j/nauka_bit_jivim

13. Баранова С.В. Концепція особистісної зрілості в умовах суспільних трансформацій. Проблеми політичної психологї ; Нац. акад. пед. наук України, Інститут соц. та політ. психології ; за заг. ред. М.М. Слюсаревського. Київ : Міленіум, 2017. Вип 5 (19). С. 133-144.

14. Паттакос А. Пленники собственных мыслей: Смысл жизни и работы по Виктору Франклу. Москва : Альпин Бизнес Букс, 2009. 205 с.

15. Baranova $\mathrm{S}$. Theoretical analysis of responsibility as an integrative quality of personality maturity in conditions of transformation. Development and modernization pedagogical and psychological sciences: the experience of Poland and the prospects of Ukraine : Collective monograph. Lublin : Izdevnieciba "Baltija Publishing", 2017 : Maria Curie-Sklodowska University. Vol. 1. P. 37-53. URL: http://repositsc.nuczu.edu.ua/bitstream/ 123456789/6063/1/colmon\%20Lublin_ped_psyh_Часть\%201_новий.pdf

\section{Information about the author:} Dr. Baranova S. V.,

$\mathrm{PhD}$, Docent at the International Society for Guided Affective Imagery Psychotherapy, Registrar of the National Awarding Organization of Ukrainian Umbrella Association of Psychotherapists (UUAP) Kyiv, Ukraine 